\title{
Studi Karakter Morfologi dan Fisiologi Varietas Padi Toleran Terhadap Cekaman Kekeringan Pada Sistem Sawah
}

\author{
Study of Morphology and Physiology Characters of \\ Rice Tolerant to Drought Stress in Lowland System \\ Maisura $^{1}$, M. A. Chozin ${ }^{2}$, Iskandar Lubis ${ }^{2}$, Ahmad Junaedi ${ }^{2}$ dan Hiroshi Ehara ${ }^{3}$ \\ 1) Program Studi Agroekoteknologi Fakultas Pertanian Universitas Malikussaleh \\ Muara Batu Lhokseumawe, Aceh, Indonesia. Email:maisuraali@ymail.com \\ 2) Program Studi Agronomi dan Hortikultura Fakultas Pertanian, Institut Pertanian Bogor \\ Jawa Barat, Indonesia \\ 3) Graduate School of Bioresources, Mie University, 1577 Kurimanchiya-cho, \\ Tsu 514-8507, Japan
}

\begin{abstract}
Abstrak
Stres air adalah salah satu faktor yang menyebabkan rendahnya hasil dataran rendah. Penelitian ini bertujuan untuk mengidentifikasi dan mengkarakterisasi morfologi dan fisiologi varietas padi toleran kekeringan. Percobaan telah dilakukan: (i) Investigasi toleransi varietas padi terhadap cekaman kekeringan pada tahap vegetatif awal di laboratorium (ii) karakter morfologi dan fisiologi varietas padi terhadap cekaman kekeringan di sawah dan (iii) menentukan karakter akar padi toleran terhadap cekaman kekeringan. Desain eksperimen yang digunakan adalah desain petak terbagi dengan tiga ulangan, dengan cekaman kekeringan sebagai plot utama dan varietas sebagai sub-plot. Hasil uji screening di laboratorium menggunakan PEG (Polyethylene Glycol) yang dapat menjadi ciri varietas padi sebagai varietas toleran kekeringan. Hasil penelitian menunjukkan bahwa periode kekeringan meningkatkan kandungan prolin pada varietas Ciherang $(25,38 \mu \mathrm{mol})$ dan IPB 3S $(22,08 \mu \mathrm{mol})$ pada 13 WAT (Minggu Setelah Transplantasi). Varietas yang memiliki kandungan gula total tertinggi dalam tahap berbunga adalah Rokan (289,38 mg.g-1DW) diikuti oleh Menthik Wangi (230,53 mg.g1DW), sedangkan kadar gula terendah dalam panen adalah Jatiluhur (17,14 mg.g-1DW). ) diikuti oleh Way Apo Buru (46.99 mg.g1DW). Varietas Jatiluhur, Way Apo Buru dan IPB 3S memiliki toleran kekeringan berdasarkan karakteristik akar. Ciherang, IPB 3S, varietas Way Apo Buru dan Jatiluhur toleran kekeringan dan potensial untuk digunakan di sawah.
\end{abstract}

Kata kunci: karakter fisiologi, konten proline, sistem akar, gula total

\begin{abstract}
Water stress is one of factors which causes low yield of lowland. This study aimed to identify and characterize morphology and physiology of drought tolerant rice varieties. Experiments which have conducted: (i) Investigation of rice varieties tolerance to drought stress at early vegetative stage in the laboratory (ii) morphology and physiology characters of rice varieties to drought stress in the paddy field and (iii) determining the character of root of rice tolerant to drought stress. The experimental design used was split plot design with 3 (three) replications, with drought stress as the main plot and the variety as sub-plot. The result of screening test at the laboratory using PEG (Polyethylene Glycol) which could characterize which rice varieties could be considered as drought tolerant varieties. Results showed that periods of drought increasing the proline content at Ciherang $(25.38 \mu \mathrm{mol})$ and IPB $3 \mathrm{~S}$ varieties $(22.08$ $\mu \mathrm{mol}$ ) at 13 WAT (Week After Transplanting). The variety that has the highest total sugar content in the flowering stage is Rokan $\left(289.38 \mathrm{mg} . \mathrm{g}^{-1} \mathrm{DW}\right)$ followed by Menthik Wangi $\left(230.53 \mathrm{mg} . \mathrm{g}^{1} \mathrm{DW}\right)$, while the lowest sugar content in harvest found in Jatiluhur (17.14 mg. $\left.\mathrm{g}^{-1} \mathrm{DW}\right)$ followed by Way Apo Buru (46.99 mg. $\left.\mathrm{g}^{-1} \mathrm{DW}\right)$. Jatiluhur, Way Apo Buru and IPB 3S varieties have drought tolerant based on the root characteristic. Ciherang, IPB 3S, Way Apo Buru and Jatiluhur varieties were drought tolerant and potential to be used in paddy field.
\end{abstract}

Keywords: physiology character, proline content, root system, total sugar 


\section{Pendahuluan}

Produksi padi sawah memiliki kontribusi yang paling besar yaitu $95 \%$ dari total produksi padi nasional (BPS 2011), sehingga peningkatan produksi tetap menjadi perhatian utama. Peningkatan produksi padi sawah terus mendapat tantangan berat, antara lain disebabkan oleh penyusutan lahan sawah subur karena beralih fungsi menjadi lahan non pertanian yang sulit untuk dihindari dan berjalan terus setiap tahun.Upaya pencetakan sawah baru menghadapi kendala yang tidak mampu mengimbangi penyusutan lahan sawah subur. Tantangan selanjutnya adalah dampak perubahan iklim yang sangat mempengaruhi produksi padi terutama pada sistem padi sawah.

Dampak perubahan iklim yang paling serius adalah dampak el nino yang mengakibatkan meningkatnya luas areal lahan sawah yang kekeringan. Hasil analisis data dampak kekeringan pada areal sawah, data Direktorat Jenderal Tanaman Pangan menunjukkan kecenderungan peningkatan luas areal yang terkena puso. Luas areal yang terkena puso akibat kekeringan mencapai 230.000 ha pada tahun 2010 dan tahun 2011 mencapai 400.000 ha (Deptan 2011).

Gagal panen akibat lahan sawah yang terkena puso akibat kekeringan akan menyebabkan terjadinya penurunan produksi padi sawah. Selain meningkatnya lahan yang terkena puso kendala lain yang dihadapi adalah masih kurang tersedia varietas yang toleran terhadap cekaman abiotik terutama terhadap cekaman kekeringan. Salah satu teknologi yang digunakan untuk dapat mengatasi permasalahan tersebut adalah dengan mengidentifikasi karakter morfologi dan fisiologi varietas yang berperan dalam toleransi terhadap cekaman kekeringan.

Respons fisiologi yang cukup penting ialah kemampuan tanaman mempertahankan tekanan turgor dengan menurunkan potensial osmotik sebagai mekanisme toleransi terhadap cekaman kekeringan. Faktor yang dapat membantu mempertahankan turgor ialah penurunan potensial osmotik dan kemampuan mengakumulasi senyawa-senyawa terlarut. Dalam proses penyesuaian osmotik, senyawasenyawa terlarut yang biasa diakumulasi ialah gula dan asam amino terutama prolin (Girousse et al. 1996 ; Szabadoz dan Savoure, 2009). Selain karakter fisiologi, sistem perakaran juga memberikan peranan yang sangat penting dalam menghadapi kondisi cekaman kekeringan.

Karakter perakaran menjadi penting pada kondisi kekeringan dimana kemampuan akar untuk menembus tanah yang padat pada sistem sawah pada saat terjadi kekeringan, untuk meningkatkan ekstraksi air pada kedalaman yang lebih dalam, penyesuaian osmotik (osmotic adjustment), dan toleransi dehidrasi daun tanaman. Sistem perakaran yang dalam, kasar dan memiliki kemampuan yang tinggi dalam membentuk percabangan akar dan penetrasi serta tingginya rasio tajuk akar adalah komponen dari sifat perakaran yang penting yang berhubungan dengan drought avoidance (Yamauchi et al. 1996; Samson et al. 2002).

\section{Bahan dan Metode}

Penelitian dilakukan di Laboratorium Ilmu dan Teknologi Benih dan di kebun percobaan Sawah Baru Babakan, Dramaga, Institut Pertanian Bogor. Penelitian dilakukan pada bulan July 2011- July 2012. Bahan yang digunakan dalam penelitian ini adalah benih 8 varietas padi, PEG BM 6000, kertas saring, aquades, sedangkan alat yang digunakan Leaf area meter, kontainer plastik, spektrofotometer UV-VIS, tensiometer, roll meter, termohigrometer, timbangan analitik, petridish dan rootbox (diadopsi dari Kono et al. 1987 dan dimodifikasi oleh Junaedi 2012).

Percobaan di laboratorium menggunakan Rancangan Acak Lengkap (RAL) yang disusun secara faktorial tiga ulangan, dimana faktor utama adalah varietas yaitu yang terdiri dari IR 64, Ciherang, IPB 3S, Way Apo Buru, Jatiluhur, Menthik Wangi, Silugonggo dan Rokan. sedangkan faktor kedua adalah konsentrasi PEG yang terdiri dari 3 taraf yaitu $0 \%, 20 \%$ dan $25 \%$. Pengamatan dilakukan terhadap panjang plumula, panjang akar dan bobot akar.

Penelitian di lapangan menggunakan rancangan split plot 3 ulangan, dengan petak utama periode kekeringan yang terdiri dari periode kekeringan setelah 3 Minggu Setelah Tanam (K-3) dan control (K0). Sedangkan sebagai anak petak varietas padi yang terdiri 8 varietas yaitu IR 64, Ciherang, IPB 3S, Way Apo Buru, Jatiluhur, Menthik Wangi, Silugonggo dan Rokan. Pengamatan dilakukan terhadap luas daun umur 12 MST (Minggu Setelah Tanam), akumulasi prolin umur 11 dan 13 MST, akumulasi gula total dan pati saat pembungaan dan saat panen, bobot gabah per rumpun. 
Penelitian studi perakaran dilaksanakan dengan menggunakan Rancangan split plot tiga ulangan, dengan petak utama periode kekeringan yaitu periode kekeringan setelah 3 Minggu Setelah Tanam (K-3) dan Kontrol (K0), sedangkan varietas sebagai anak petak yaitu varietas IR 64, Ciherang, IPB 3S, Way Apo Buru, Jatiluhur, Menthik Wangi, Silugonggo dan Rokan. Pengamatan dilakukan terhadap kedalaman capaian akar dan bobot total akar. Seluruh data pengamatan percobaan dianalisis menggunakan analisis ragam pada taraf uji $\alpha=$
0.05 dan analisis lanjut menggunakan uji Duncan's Multiple Range Test (DMRT).

\section{Hasil dan Pembahasan}

\section{Respon karakter morfologi pada fase vegetatif awal terhadap kekeringan}

Faktor konsentrasi PEG, varietas dan interaksi berpengaruh sangat nyata terhadap pertumbuhan panjang plumula dan panjang akar seminal (Tabel 1dan 2).

Tabel 1. Rata-rata panjang plumula $(\mathrm{cm})$ pada delapan varietas dengan tiga konsentrasi PEG

\begin{tabular}{lccccc}
\hline \multirow{2}{*}{ Varietas } & \multicolumn{5}{c}{ Konsentrasi PEG } \\
\cline { 2 - 6 } & & \multicolumn{5}{c}{ penurunan } & penurunan \\
& relatif $(\%)$ & $25 \%$ & relatif $(\%)$ \\
\hline IR 64 & $7.27 \mathrm{bc}$ & $4.41 \mathrm{fg}$ & 39.34 & $1.72 \mathrm{j}$ & 76.34 \\
Ciherang & $8.12 \mathrm{ab}$ & $5.58 \mathrm{~d}$ & 31.28 & $4.52 \mathrm{efg}$ & 44.33 \\
IPB 3S & $8.07 \mathrm{ab}$ & $5.30 \mathrm{de}$ & 34.32 & $3.70 \mathrm{gh}$ & 54.15 \\
Way Apo Buru & $8.53 \mathrm{a}$ & $5.28 \mathrm{de}$ & 38.1 & $3.15 \mathrm{hi}$ & 63.07 \\
Jatiluhur & $7.14 \mathrm{bc}$ & $5.94 \mathrm{~d}$ & 16.81 & $2.951 \mathrm{hi}$ & 58.68 \\
Menthik Wangi & $7.82 \mathrm{abc}$ & $5.60 \mathrm{~d}$ & 28.39 & $3.36 \mathrm{hi}$ & 57.03 \\
Silugonggo & $7.27 \mathrm{bc}$ & $4.35 \mathrm{fg}$ & 40.17 & $2.70 \mathrm{i}$ & 62.86 \\
Rokan & $7.17 \mathrm{c}$ & $4.73 \mathrm{ef}$ & 34.03 & $4.62 \mathrm{ef}$ & 35.56 \\
\hline
\end{tabular}

Keterangan: Angka-angka pada kolom yang sama yang diikuti oleh huruf yang sama tidak berbeda nyata pada taraf 5\% menurut uji DMRT.

PEG menginduksi terjadi kekeringan yang menyebabkan terjadinya penurunan panjang plumula dan panjang akar pada beberapa varietas. Verslues et al. (2006) melaporkan bahwa penurunan pertumbuhan akar dan tunas terjadi karena PEG mengikat air sehingga menjadi tidak tersedia bagi tanaman. Pada konsentrasi $25 \%$ upaya untuk pemanjangan akar semakin menghambat pertumbuhan plumula.

Tabel 2. Rata-rata panjang akar $(\mathrm{cm})$ pada delapan varietas dengan tiga konsentrasi PEG

\begin{tabular}{|c|c|c|c|c|c|}
\hline \multirow{3}{*}{ Varietas } & \multicolumn{5}{|c|}{ Konsentrasi PEG } \\
\hline & & & penurunan & & penurunan \\
\hline & (kontrol) & $20 \%$ & relatif $(\%)$ & $25 \%$ & relatif $(\%)$ \\
\hline IR 64 & $6.18 \mathrm{jk}$ & $6.58 \mathrm{ij}$ & $6.47 *$ & $3.92 \mathrm{k}$ & 36.57 \\
\hline Ciherang & $7.40 \mathrm{ghi}$ & $7.77 \mathrm{fgh}$ & $5.00 *$ & $6.30 \mathrm{ij}$ & 14.86 \\
\hline IPB $3 S$ & $11.14 \mathrm{a}$ & 9.59 cde & 13.91 & $8.81 \mathrm{def}$ & 20.92 \\
\hline Way Apo Buru & $6.53 \mathrm{ij}$ & $5.07 \mathrm{k}$ & 22.36 & $5.98 \mathrm{jk}$ & 8.42 \\
\hline Jatiluhur & $9.88 \mathrm{bcd}$ & $10.86 \mathrm{ab}$ & $9.92 *$ & 8.71 ef & 11.84 \\
\hline Menthik Wangi & $10.26 a b c$ & 8.68 ef & 15.4 & $5.83 \mathrm{jk}$ & 43.18 \\
\hline Silugonggo & 9.57 cde & $6.17 \mathrm{jk}$ & 35.53 & $7.96 \mathrm{fg}$ & 16.82 \\
\hline Rokan & $6.18 \mathrm{jk}$ & $6.74 \mathrm{hij}$ & $9.06^{*}$ & 6.84 ghij & $10.67 *$ \\
\hline
\end{tabular}

Keterangan: Angka-angka pada kolom yang sama yang diikuti oleh huruf yang sama tidak berbeda nyata pada taraf 5\% menurut uji DMRT.*= peningkatan

Varietas IR 64 yang termasuk varietas peka terhadap cekaman kekeringan, hal ini dapat dilihat dari penurunan relatif yang paling tinggi pada 25\% PEG. Zapico et al. (2008) menyatakan bahwa pada konsentrasi $15 \%$ PEG
6000 perkecambahan genotipe padi sawah lebih peka dibandingkan padi gogo. Peningkatan panjang akar dan bobot kering akar akibat perlakuan 20\% PEG terdapat pada varietas Jatiluhur dan Rokan. Meningkatnya panjang akar 
dan bobot kering akar pada konsentrasi 20\% pada beberapa varietas menunjukkan tingkat toleransi terhadap cekaman kekeringan yang diuji (Leisham \& Westoby 1994).

Perbedaan mekanisme toleransi terhadap cekaman kekeringan tiap varietas diantaranya melalui peningkatan bobot akar dan pemanjangan akar untuk menjangkau lapisan air yang lebih dalam. Gambar 1 memperlihatkan bobot akar tertinggi terdapat pada varietas IPB
3S diikuti Jatiluhur pada konsentrasi 20\% PEG. Kemampuan akar untuk menyerap air pada kondisi kering juga menjadi ukuran dalam mengidentifikasi varietas toleran terhadap kekeringan. Sifat fisik berupa perakaran yang panjang, padat, dan diameter akar yang besar menjadi tolok ukur galur/varietas padi toleran kekeringan (De Datta 1975; Suardi \& Haryono 1988; Mackill et al.1996; Gowda et al. 2011).

Gambar 1. Bobot akar pada 8 varietas dengan tiga konsentrasi PEG

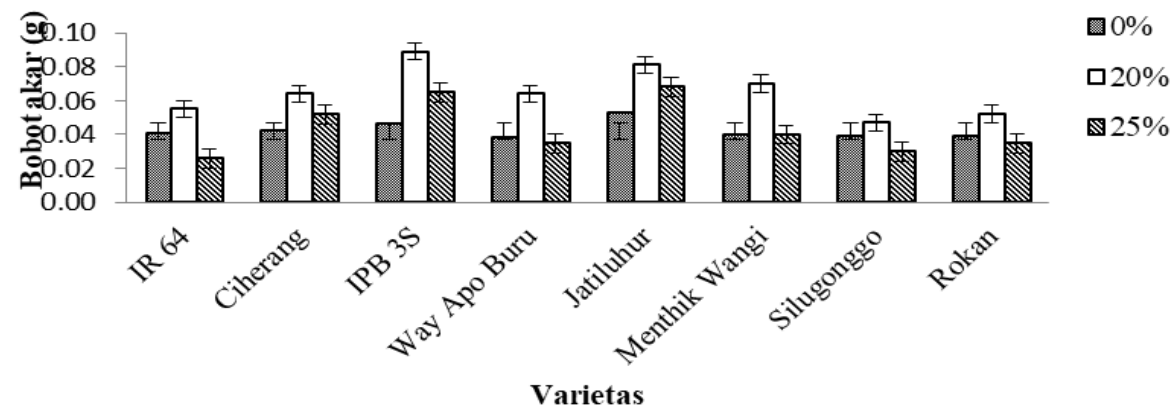

Hasil analisa korelasi (tidak ditampilkan) menunjukkan adanya korelasi antara panjang akar dan panjang plumula terhadap bobot akar. Hal ini menunjukkan bahwa peubah bobot akar, panjang akar dan panjang plumula memberikan kontribusi dalam penentuan tingkat toleransi suatu varietas terhadap kekeringan.

Karakter morfologi dan fisiologi varietas toleran kekeringan pada sistem sawah

Perlakuan periode kekeringan, varietas dan interaksi berpengaruh sangat nyata terhadap luas daun pada umur 12 MST. Periode kekeringan menyebabkan terjadinya penurunan luas daun pada semua varietas pada periode kekeringan K3. Varietas IR 64 memiliki luas daun paling kecil pada periode kekeringan $\mathrm{K} 3$
(Gambar 2). Luas daun juga berkaitan dengan panjang plumula pada fase awal vegetatif dimana varietas IR 64 juga memiliki panjang plumula paling pendek. Luas daun merupakan salah satu karakter morfologi tanaman yang berperan penting dalam penentuan produksi tanaman.

Periode kekeringan berpengaruh terhadap luas daun juga berpengaruh nyata terhadap akumulasi prolin (Tabel 3). Periode kekeringan menyebabkan terjadinya peningkatan akumulasi prolin terutama pada varietas IR 64 yang diikuti Ciherang pada umur 11 MST, sedangkan pada umur 13 MST, prolin tertinggi terdapat pada varietas Ciherang dan IPB 3S pada periode kekeringan $\mathrm{K} 3$.

Gambar 2. Luas daun 8 varietas pada 2 (dua) periode kekeringan

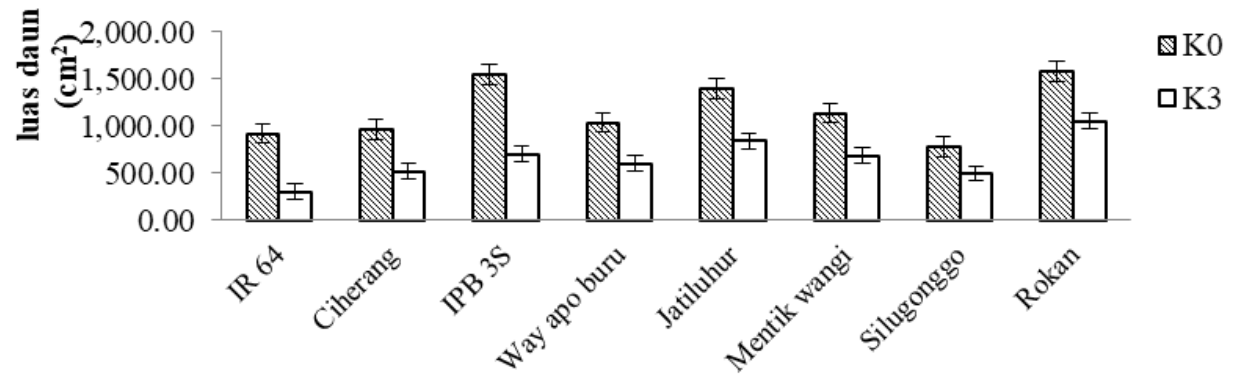

Periode kekeringan 
Akumulasi prolin merupakan respon awal tanaman ketika mengalami kekurangan air (water deficit) dan berperan untuk mengurangi kerusakan sel (Anjum et al. 2011). Akumulasi prolin tidak hanya terjadi pada varietas yang toleran ketika terjadi cekaman kekeringan tetapi juga meningkat pada varietas yang peka. Namun varietas-varietas yang toleran kekeringan mengakumulasikan prolin dalam jangka waktu yang lebih lama dibandingkan dengan varietas peka (Saruhan et al. 2006). Hal ini ditunjukkan oleh varietas Silugonggo, Rokan dan IR 64 yang termasuk varietas yang peka yang pada umur 11 MST mengakumulasi konsentrasi prolin yang tinggi dibandingkan varietas lainnya. Meskipun demikian pada umur 13 MST terjadinya penurunan konsentrasi prolin pada varietas Rokan yang diikuti Silugonggo dan IR 64. Hal ini dapat dilihat pada Gambar 3 yang menyajikan perbedaan dari kedua mekanisme dari varietas yang toleran dan yang peka terhadap akumulasi prolin pada umur 11 dan 13 MST.

Tabel 3. Kandungan prolin pada umur 11 MST dan 13 MST pada 8 varietas padi pada dua periode kekeringan

\begin{tabular}{|c|c|c|c|c|c|c|c|c|}
\hline \multirow{3}{*}{ Varietas } & \multicolumn{4}{|c|}{$11 \mathrm{MST}$} & \multicolumn{4}{|c|}{$13 \mathrm{MST}$} \\
\hline & \multicolumn{4}{|c|}{ Periode kekeringan } & \multicolumn{4}{|c|}{ Periode kekeringan } \\
\hline & \multicolumn{2}{|l|}{ K0 } & \multicolumn{2}{|l|}{$\mathrm{K} 3$} & \multicolumn{2}{|c|}{ K0 } & \multicolumn{2}{|c|}{$\mathrm{K} 3$} \\
\hline & \multicolumn{4}{|c|}{$\mu \mathrm{mol} . \mathrm{g}^{-1} \mathrm{BB}$} & \multicolumn{4}{|c|}{$\mu \mathrm{mol} . \mathrm{g}^{-1} \mathrm{BB}$} \\
\hline IR 64 & 36.03 & $a b c$ & 41.90 & $\mathrm{a}$ & 21.92 & $\mathrm{~b}$ & 21.04 & B \\
\hline Ciherang & 32.16 & $b-f$ & 39.80 & $a b$ & 18.66 & $\mathrm{bc}$ & 28.79 & A \\
\hline IPB $3 \mathrm{~S}$ & 21.56 & g & 23.63 & $\mathrm{fg}$ & 14.89 & def & 25.98 & A \\
\hline Way Apo Buru & 27.56 & d-g & 24.50 & $\mathrm{fg}$ & 14.47 & def & 19.35 & $\mathrm{Bc}$ \\
\hline Jatiluhur & 24.13 & $\mathrm{fg}$ & 24.07 & fg & 14.2 & def & 17.04 & $\mathrm{Cd}$ \\
\hline Menthik Wangi & 34.80 & $a-d$ & 24.33 & $a-d$ & 12.28 & ef & 12.34 & Ef \\
\hline Silugonggo & 29.03 & $\mathrm{c}-\mathrm{g}$ & 35.63 & $a-d$ & 14.08 & def & 14.25 & Def \\
\hline Rokan & 25.93 & efg & 33.96 & a-e & 12.13 & $\mathrm{f}$ & 16.16 & Cde \\
\hline
\end{tabular}

Keterangan : Angka-angka pada kolom yang sama yang diikuti oleh huruf yang sama tidak berbeda nyata pada taraf 5\% menurut uji DMRT.

Gambar 3. Akumulasi prolin pada varietas Ciherang (toleran) dan IR 64 (peka) pada umur 11 MST dan 13 MST pada 2 periode kekeringan

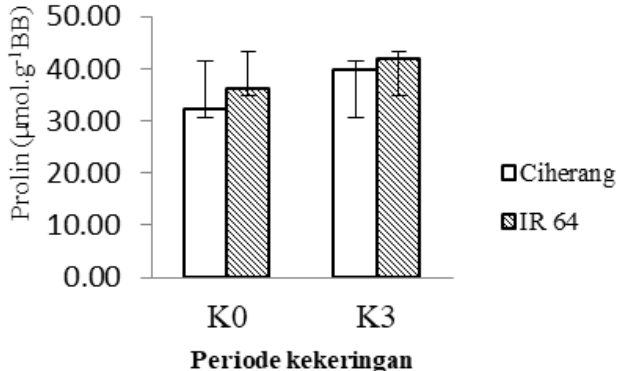

Penghentian pemberian air yang lebih awal juga menyebabkan meningkatnya akumulasi gula total saat pembungaan dan saat panen. Varietas-varietas yang relatif toleran mengakumulasikan gula total pada bagian batang tanaman dan kemudian mentranslokasikan ke bagian organ lain untuk metabolisme dan pertumbuhan, sedangkan varietas yang peka juga

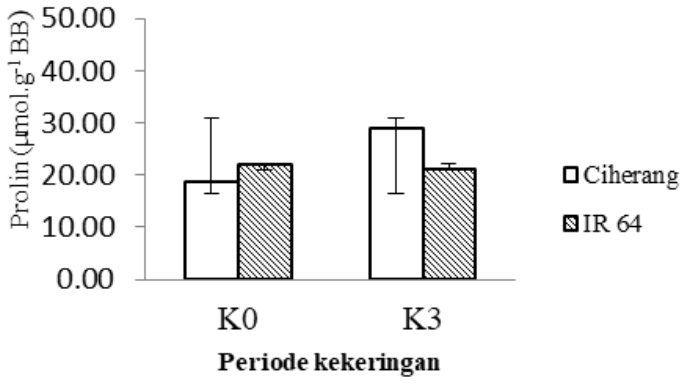

mengakumulasikan gula total yang tinggi pada bagian batang tanaman pada tahap pembungaan, namun ketika terjadi cekaman kekeringan terjadi penghambatan translokasi gula total ke bagian lain tanaman terutama ke bagian biji. Hal ini dapat dilihat pada varietas toleran Jatiluhur yang mengakumulasikan gula total dalam konsentrasi yang tidak berbeda nyata antara kontrol dengan 
kekeringan. Pada saat panen baik pada perlakuan kontrol dan kekeringan, retranslokasi gula total pada varietas Jatiluhur tidak mengalami penghambatan ke bagian biji, sedangkan pada varietas peka (Menthik Wangi) mengalami penghambatan retranslokasi gula total pada perlakuan kekeringan. Akumulasi gula total masih tinggi konsentrasinya pada saat panen (Gambar 4).
Pada kondisi cekaman kekeringan akumulasi dari gula total meningkat pada bagianbagian tanaman (Hu et al. 2006). Akumulasi gula total pada bagian organ varietas yang toleran lebih efektif karena stabilitas membran yang lebih tinggi dan kehilangan air yang lebih rendah dibandingkan dengan varietas yang peka (Valentovic et al. 2006).

Gambar 4. Akumulasi gula total pada varietas toleran (Jatiluhur) dan varietas peka (Menthik Wangi) pada saat pembungaan (kiri) dan panen (kanan) pada 2 periode kekeringan.

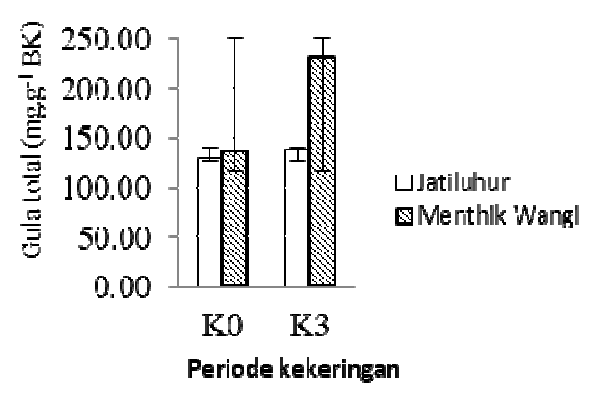

Perlakuan periode kekeringan tidak berpengaruh nyata terhadap kandungan pati, namun varietas dan interaksi berpengaruh sangat nyata terhadap kandungan pati pada bagian batang tanaman padi pada saat pembungaan, sedangkan kandungan pati pada saat panen sangat dipengaruhi oleh periode kekeringan, varietas dan interaksinya (Tabel 4). Menthik Wangi memiliki kandungan pati tertinggi yang disimpan pada bagian batang pada fase pembungaan, sedangkan pada saat panen

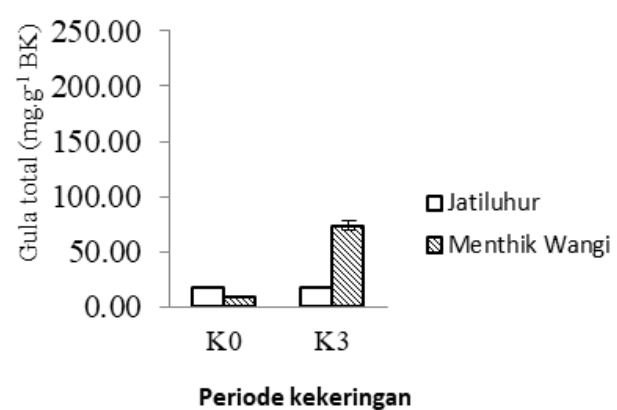

kandungan pati tertinggi juga terdapat pada varietas Menthik wangi pada periode kekeringan K3(Gambar 5). Beberapa hasil penelitian menunjukkan bahwa apabila varietas/ genotipe yang toleran terhadap cekaman kekeringan memiliki kemampuan mensintesis dan menyimpan karbohidrat terlarut dalam batang dengan konsentrasi yang tinggi pada fase anthesis maka akan cenderung dapat meningkatkan hasil (Gupta et al. 2011).

Tabel 4. Kandungan pati pada tahap pembungaan dan saat panen 8 varietas padi pada dua periode kekeringan

\begin{tabular}{|c|c|c|c|c|c|c|c|c|}
\hline \multirow[b]{2}{*}{ Varieties } & \multicolumn{4}{|c|}{$\begin{array}{c}\text { Pembungaan } \\
\text { Periode kekeringan }\end{array}$} & \multicolumn{4}{|c|}{$\begin{array}{c}\text { Panen } \\
\text { Periode kekeringan }\end{array}$} \\
\hline & \multicolumn{2}{|c|}{ K0 } & \multicolumn{2}{|l|}{$\mathrm{K} 3$} & \multicolumn{2}{|c|}{ K0 } & \multicolumn{2}{|c|}{$\mathrm{K} 3$} \\
\hline & \multicolumn{4}{|c|}{$\mathrm{mg} \cdot \mathrm{g}^{-1} \mathrm{BK}$} & \multicolumn{4}{|c|}{$\mathrm{mg} \cdot \mathrm{g}^{-1} \mathrm{BK}$} \\
\hline IR 64 & 372.77 & de & 444.82 & $\mathrm{ab}$ & 426.80 & $\mathrm{a}$ & 337.33 & bcd \\
\hline Ciherang & 387.35 & $\mathrm{~cd}$ & 403.95 & bcd & 303.31 & $\mathrm{~cd}$ & 274.65 & $\mathrm{~d}$ \\
\hline IPB $3 \mathrm{~S}$ & 435.12 & $a b c$ & 357.67 & de & 336.04 & bcd & 349.80 & bcd \\
\hline Way Apo Buru & 450.49 & $a b$ & 472.00 & $\mathrm{a}$ & 344.97 & $\mathrm{bc}$ & 450.39 & $\mathrm{a}$ \\
\hline Jatiluhur & 376.98 & de & 326.81 & $\mathrm{e}$ & 324.48 & $\mathrm{~cd}$ & 340.44 & bcd \\
\hline Menthik Wangi & 470.37 & $\mathrm{a}$ & 465.79 & $\mathrm{a}$ & 315.75 & $\mathrm{~cd}$ & 397.70 & $\mathrm{ab}$ \\
\hline Silugonggo & 456.21 & $\mathrm{a}$ & 353.58 & de & 445.60 & $\mathrm{a}$ & 296.89 & $\mathrm{~cd}$ \\
\hline Rokan & 448.39 & $a b$ & 354.05 & de & 459.81 & $\mathrm{a}$ & 328.31 & $\mathrm{~cd}$ \\
\hline
\end{tabular}


Yang et al. (2001) melaporkan bahwa kekeringan akan menyebabkan meningkatnya enzim $\alpha$-amilase sehingga menghidrolisis pati dengan cepat dan meningkatnya remobilisasi karbon didalam batang tanaman padi. Pati yang disimpan dibagian batang berperan sebagai buffer untuk menjaga laju pengisian biji, khususnya ketika fotosintesis terganggu karena kekeringan. Jika tanaman mengalami kekeringan setelah anthesis maka saat pengisian biji hingga panen sangat tergantung pada cadangan pati yang disimpan pada bagian batang dan kontribusinya mencapai 22-60 persen (Blum et al.1994).

Gambar 5. Kandungan pati pada varietas toleran (Jatiluhur) dan varietas peka (Menthik Wangi) pada saat pembungaan (kiri) dan saat panen (kanan) pada 2 periode kekeringan

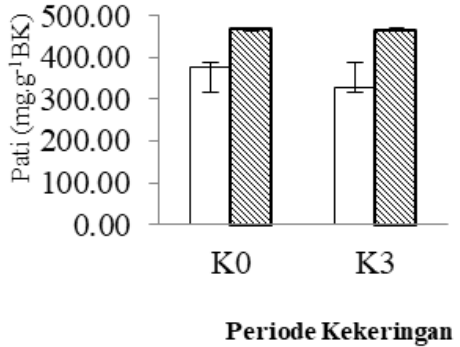

Adanya hubungan antara kandungan pati dan remobilisasi kandungan pati saat panen dengan hasil. Perlakuan periode kekeringan, varietas dan interaksi berpengaruh nyata terhadap hasil bobot gabah per rumpun. Bobot gabah per rumpun menurun tajam dengan lamanya periode kekeringan pada periode K3. Penurunan bobot gabah tertinggi terjadi pada varietas Menthik Wangi yang mencapai 79.70 persen dan sebaliknya penurunan bobot gabah per rumpun paling rendah terdapat pada varietas

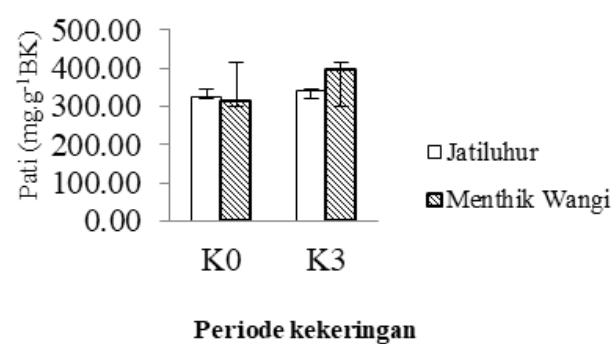

Jatiluhur yaitu 35.09 persen pada periode kekeringan K3. Gambar 6 memperlihatkan perbedaan penurunan bobot gabah perrumpun pada varietas toleran dan peka. Varietas-varietas yang peka umumnya menghasilkan gabah yang tinggi pada kondisi yang normal, sebaliknya apabila terjadi cekaman maka akan terjadi penurunan hasil yang sangat nyata bahkan melebihi 50 persen dari kondisi normal. Sedangkan varietas yang toleran memperlihatkan hasil gabah yang lebih stabil ( Liu et al. 2008).

Gambar 6. Bobot gabah perrumpun pada varietas toleran (Jatiluhur) dan varietas peka (Rokan)

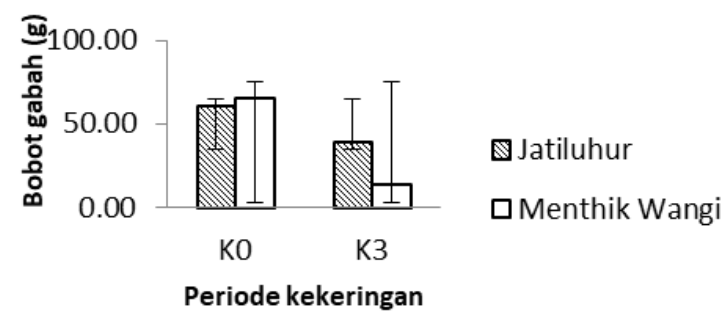

\section{Karakter perakaran varietas toleran terhadap kekeringan}

Perlakuan periode kekeringan, varietas serta interaksi sangat nyata terhadap total bobot akar dan kedalaman capaian akar. Total bobot akar dan kedalaman capaian akar lebih tinggi pada varietas Jatiluhur pada periode kekeringan K3. Hal ini menunjukkan sistem perakaran pada varietas Jatiluhur yang memiliki sistem perakarannya yang lebih dalam, menyebabkan pertumbuhan akar yang lebih vertikal, potensial menyerap air dan nutrien pada lapisan tanah yang lebih dalam (Gowda et al. 2011), sedangkan tipe padi sawah menunjukkan penyebaran akar yang lebih horizontal (Ciherang, IR 64, Menthik Wangi). Hal ini menunjukkan bahwa perakaran yang dangkal akan mengalami keterbatasan dalam mengekstrak air dibawah kedalaman $60 \mathrm{~cm}$ (Fukai \& Ithapan 1988). Varietas peka terhadap cekaman kekeringan memperlihatkan penurunan bobot akar yang lebih besar dan kedalaman capaian akar juga lebih rendah dibandingkan dengan varietas yang toleran (Gambar 7). 
Gambar 7. Bobot akar dan kedalaman capaian akar pada varietas toleran (Jatiluhur) dan varietas peka (Rokan)

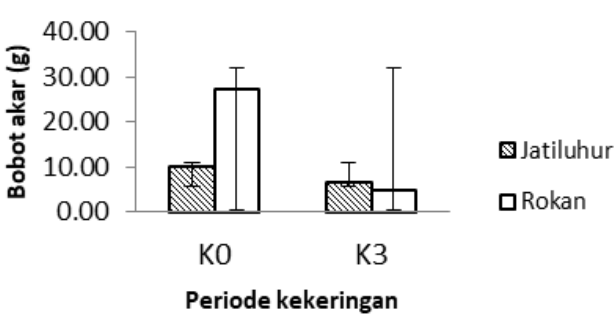

Hasil penelitian Toorchi et al. (2006) dan Kanbar et al. (2009) karakter kedalaman capaian akar dan bobot kering akar memberikan kontribusi terhadap peningkatan hasil pada kondisi cekaman pada tanaman padi. Analisa korelasi pada penelitian ini menunjukkan bahwa bobot akar berkorelasi dengan bobot gabah per rumpun (data tidak ditampilkan). Hal ini menunjukkan bahwa karakter bobot akar dapat dijadikan sebagai indikator dalam mengelompokkan varietas yang toleran terhadap kekeringan.

\section{Kesimpulan}

Dari hasil penelitian ini dapat disimpulkan sebagai berikut:

1. Hasil uji cepat dengan menggunakan PEG cukup berkesesuaian dengan hasil yang diuji di lapangan.

2. Beberapa karakter morfologi dan fisiologi tanaman yang berperan dalam menghadapi cekaman kekeringan yaitu meningkatnya akumulasi prolin dalam waktu yang lebih lama, yang ditunjukkan oleh varietas Ciherang dan IPB 3S.Aktif terjadinya retranslokasi cadangan asimilat (gula total) yang ditunjukkan oleh varietas Jatiluhur dan Way Apo Buru. Varietas Jatiluhur menunjukkan kandungan pati paling rendah pada saat panen.

3. Karakter perakaran yang berperan dalam menghadapi cekaman kekeringan adalah kedalaman capaian akar dan meningkatnya total bobot akar. yang ditunjukkan oleh varietas Jatiluhur

\section{Daftar Pustaka}

Anjum SA, Xie XY, Wang LC, Saleem M. 2011. Morphological, physiological and biochemical responses of plants to drought stress. Agric Res 9: 2026-2032.

Blum A, Sinmena B, Mayer J, Golan G, Shpiler L. 1994. Stem reserve mobilisation

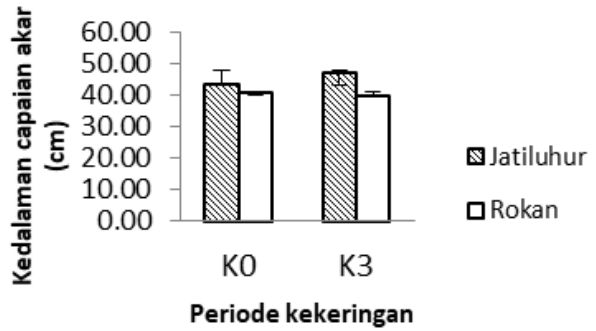

supports wheat-grain fi lling under heat stress. Aust. J. Plant Physiol 21:771-781.

[BPS] Badan Pusat Statistik. 2011. Luas tanam, produktivitas dan produksi tanaman padi seluruh Indonesia. BPS. Jakarta.

De Datta SK. 1981. Principles and practices of rice production. A Wiley-Interscience Publication. John Wiley \& sons, New york. 618p.

Departemen Pertanian. 2011. Deskripsi varietas padi. Balai Besar Penelitian Tanaman Padi. Badan Penelitian dan Pengembangan Pertanian. Sukamandi.

Fukai S, P Inthapan. 1988. Growth and yield of rice cultivars under sprinkler irriga- tion in south-eastern Queensland. 3. Water extraction and plant water relations. Exp Agric 28: 249-252.

Gowda VRP, Hendry A, Yamauchi A , Shashidhar HE, Serraj R. 2011. Root biology and genetic improvement for drought avoidance in rice. Field Crop Res 22:1-13.

Girousse CR, Bournovill, Bonemain JL. 1996. Water deficit induced changes in concentration in proline and some other amino acid in floem sap of alfalfa. Plant Physiol 1: 109-113.

Gupta AK, Kaur K, Kaur N. 2011. Stem reserve mobilization and sink activity in wheat under drought conditions. Plant Sci 2: 7077.

Hu H, Dai M, Yao J, Xiao B, Li X, Zhang Q, Xiong L. 2006. Overexpressing a NAM, ATAF and CUC (NAC) transcription factor enhances drought resistance and salt tolerance in rice Proceedings of the National Academy of Sciences of the United States of America 35: 1298712992.

Kanbar A, Toorchi M, Shashidhar HE. 2009. Relationship between yield and root 
morphological characters in rainfed lowland rice(Oryza sativa L). Cereal Res Commun 37 : 261-268.

Kono Y, Yamauchi A, Nonoyama T, Tatsumi J, Kawamura N. 1987. A revised experimental system of root-soil interaction for laboratory work. Biol 4:141-151.

Leishman M, Westoby RM. 1994. The role of seed size in seedling establishment in dry soil conditions experimental evidence from semi arid species. Eco. 82: 249-258.

Liu K, Ye Y, Tang C, Wang Z, Yang J . 2008. Responses of ethylene and ACC in rice grains to soil moisture and their relations to grain filling. Frontiers of Agriculture in China $2: 172-180$.

Mackill DJ, Coffman WR, Garrity DP. 1996. Rainfed Lowland Rice improvement. IRRI.

Suardi D, Haryono S. 1994. Keragaan sifat toleransi galur/varietas padi terhadap cekaman kekeringan, hal. 158-159. Dalam Mahmud (ed.). Risalah Hasil Penelitian Tanaman Pangan No.3. Balai Penelitian Tanaman Pangan Bogor.

Samson BK, Hasan H, Wade LJ. 2002. Penetration of hardpans by rice lines in the rainfed lowlands. Field Crops Res 76:175-188.

Saruhan N, Terzi R, Kadioglu A. 2006. The effects of exogenous polyamines on some biochemical changes during drought Ctenanthe setosa. Acta Biol Hungarica 57: 221-229.
Szabados L, Savoure A. 2009. Proline: a multifunctional amino acid. Trends in Plant Sci 15:89-97.

Toorchi M, Shashidhar HE, Sridhara H. 2006. Influence of the root system on grain yield and related traits in rainfed lowland rice(Oryza sativa L.). Biol. Sci 9: 22672272.

Valentovič P, Luxová L, Kolarovič L, Gašparíková O. 2006. Effect of osmotic stress on compatible solutes content, membrane stability and water relations in two maize cultivars. Plant Soil Environ 52: 186-191.

Verslues PE, Agarwal M, Agarwal KS, Zhu J. 2006. Methods and concepts in quantifying resistance to drought, salt and freezing, abiotic stresss that affect plant water status.The plant 45:523-539.

Yamauchi Y, Pardales JR, Kono Y. 1996. Root system structure and its relation to stress tolerance. In: Ito, O.Toole, et al. (Eds.), Roots and Nitrogen in Cropping Systems of the Semi-Arid Tropics. JIRCAS Publication, Tsukuba, Japan.

Yang J, Zhang J, Wang Z, Zhu Q, Wang W. 2001. Hormonal changes in the grains of rice subjected to water stress during grain filling. Plant Physiol 127: 315-323.

Zapico FL. Miranda JG, Pare MI. 2008. Physiological characterization for drought tolerance of selected rice varieties in Lake Sebu, Philippine. USM R \& D J 16:13-16. 